\title{
Inclusion of Spirulina in Floating Fish Feed Production: Protein and Physical Quality
}

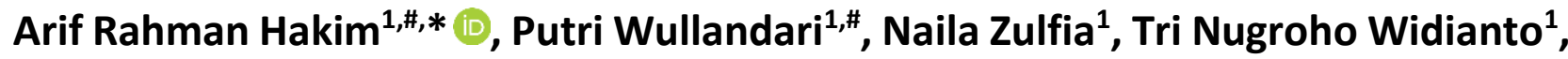 \\ Bakti Berlyanto Sedayu ${ }^{1}$
}

\begin{abstract}
${ }^{1}$ Research Institute for Fisheries Postharvest Mechanization, Ministry of Marine Affairs and Fisheries Republic of Indonesia, Jl. Imogiri Barat KM 11.5, Yogyakarta, Indonesia 55781

\#These authors share the first authorship.
\end{abstract}

\section{How to cite}

Hakim, A.R., Wullandari, P., Zulfia, N., Widianto, T.N., Sedayu, B.B. (2021). Inclusion of Spirulina in Floating Fish Feed Production: Protein and Physical Quality. Aquaculture Studies, 21, 161-167. http://doi.org/10.4194/2618-6381-v21_4_03

\section{Article History}

Received 14 March 2021

Accepted 24 June 2021

First Online 30 June 2021

Corresponding Author

Tel.: +6281334781593

E-mail: arif.hakim@kkp.go.id

\section{Keywords}

Substitution

Fish meal

Microalgae

Protein content

Physical quality

\begin{abstract}
The objective of this study was to investigate effects of Spirulina meal (SM) inclusion in fish feed formulations on their physical and protein content. Four formulations of fish feed were carried out i.e. a control diet with fishmeal (FM) as the single protein source and three others formulations containing Spirulina meal (SM) ingredient in different ratios of FM:SM (w/w) namely 75:25; 50:50 and 25:75 (w/w). All the formulations were processed into pellets using an extruder with a $600 \mathrm{rpm}$ screw speed, $100^{\circ} \mathrm{C}$ barrel temperature, and $3 \mathrm{~mm}$ diameter of dies. The dried pellets were then evaluated with respect to the protein content and physical properties i.e. expansion ratio, unit density, floatability and hardness. In general, the most optimum pellet formulation was found at the ratio of 25:75 (FM: SM) ingredients resulted in pellet with higher protein (38.89\%) and expand ratio (1.65 fold), the lowest unit density $(0.473 \mathrm{mg} / \mathrm{mm} 3)$, the highest floatability $(100 \%)$ and less hardness $(32.53 \mathrm{~N})$. Therefore, formulation of floating fish feed included with Spirulina are an option for improving its protein content and physical properties.
\end{abstract}

\section{Introduction}

The need for fish feed increases continuously along with the production growth of aquaculture in Indonesia (Ministry of Marine Affairs and Fisheries, 2017). Fish feed is majorly comprised of fishmeal which brings about some issues such as high production cost, as well as lack of supply availability due to overexploitation of fisheries resources and competition with people's food or livestock (Martin et al., 2019 ; Raji et al., 2018). To address these problems, search on alternative protein sources for fish feed formulation is needed.

In recent years, researchers and aquaculturists have been attracted to explore microalgae for alternative protein sources, and among the species of microalgae, Spirulina sp. shows a high potential to be used in fishmeal production (Sheikhzadeh et al., 2019). Spirulina $\mathrm{sp}$ is a blue-green alga which contains rich nutritional substances such as protein (60-70\%), vitamins B12, $\beta$-carotene and minerals with particular iron content. Furthermore, Spirulina sp could also be cultivated easily in either an indoor or outdoor environment (Zhang et al., 2015). Previous researches have showed several advantages of the Spirulina $\mathrm{sp}$ utilization in the fish farming in particularly as feed or supplements. Raji et al. (2018) reported that dietary of Spirulina platensis and Chlorella vulgaris in American catfish farming successfully increased the feed efficiency and fish growth. Moreover, Laining et al. (2017) also observed that the supplementation of Spirulina meal in 
the pre-maturation diet of tiger shrimp noticeably improved their biomass. Study by Khanzadeh et al. (2016) showed that utilization of Spirulina in fish feed production has not economically feasible yet for the fishmeal replacement, but it compensates as reproductive performance promoter, increased eggs viability and survival rate of larvae, as well as increased feeding efficiency and protein and fat retention in some fish farming (Nainggolan et al., 2015; Bambang et al., 2012).

Most of studies on Spirulina inclusion in fish feed were focused on the nutritional properties' aspects and its influence to the fish growth. Nevertheless, its effects on the physical characteristics of the fish feed produced have not been reported yet, particularly when Spirulina meal is incorporated into floating fish feed formulation. Reported by Hakim, et al., 2019)that the production of floating fish feed was affected by gelatinization process in the extruders whereby its ingredients primarily consist of protein, starch, fat and water. They would experience a complex process during manufacture. Thereof, when attempting to replace or change the fishmeal levels in floating fish feed, both alternative high protein meals and combined starch-protein sources should be taken into consideration (Kraugerud et al., 2011).

The addition of Spirulina in floating fish feed formulation may find new challenges in particularly during the extrusion process. This may be caused by the interruption of starch gelatinization process by the Spirulina addition, and eventually lipid-amylose complexes can also be formed, sparking the crystallization of V-type structures (Martínez-Sanz et al., 2018). Therefore, this study investigates the effect of Spirulina meal as ingredients on the protein content and physical characteristics of the floating fish feed produced by using extrusion method.

\section{Materials and Methods}

Fish feed ingredients consist of fishmeal, spirulina meal, soybean meal, corn flour and tapioca flour. Fishmeal was purchased from PT Central Proteina Prima (Indonesia). Spirulina meal, a dried microalga of Spirulina sp., was obtained from PT Polaris Indonesia. While other ingredients such as soybean meal (Hasil Bumiku Brand), corn (Maizenaku Brand) and tapioca flour (Produced by Rose Brand PT. Budi Acid Jaya) purchased from supplier feed shop locally. The proximate chemical compositions of the ingredients are listed in Table 1.

Four different fish feed formulations were prepared as presented in Table 2 including a control diet containing fishmeal as the single protein source and three other diets formulations containing Spirulina meal ingredients with various level of addition to partially replaced the fishmeal content. A one $\mathrm{kg}$ from each formulation was added with $250 \mathrm{~g}$ of water and mixed using a Stand Twin Shaft mixer (Trisonic T-1505) for 20 minutes. The mixtures were allowed to stand for an hour to obtain moist stability. The formulations were then extruded in a counter-rotating twin-screw extruder which was adjusted at $600 \mathrm{rpm}$, and a $100^{\circ} \mathrm{C}$ barrel temperature with a $\varnothing 3 \mathrm{~mm}$ die outlet. The extruder is designed by Hakim et al. (2020). The extruded formulations were cut into a $0.5-1 \mathrm{~cm}$ extrudate and cooled to room temperature. After that, they were dried in a rotary dryer $\left( \pm 40^{\circ} \mathrm{C}\right)$ until the moisture content reached around $10-12 \%$ (wet basis). Sampling on the fish feed pellets was taken after a steady-state condition was reached (approximately $30 \mathrm{~min}$ ) and the representative samples were prepared for further analysis.

Tabel 1. Chemical composition of feedstuff

\begin{tabular}{lcccc}
\hline Ingredients & Protein (\%) & Lipid (\%) & Ash (\%) & Moisture (\%) \\
\hline Spirulina meal & 67.99 & 0.01 & 7.17 & 5.86 \\
Fishmeal & 61.37 & 2.83 & 19.13 & 8.59 \\
Corn flour & 8.80 & 6.40 & 2.15 & 10.98 \\
Soybean meal & 45.55 & 9.68 & 6.42 & 9.41 \\
Tapioca flour & 0.50 & 0.30 & 0.20 & 9.67 \\
\hline
\end{tabular}

Table 2. Feed ingredients, formulations and nutrients composition

\begin{tabular}{lcccc}
\hline & & \multicolumn{2}{c}{ Ratio } \\
\cline { 3 - 5 } Ingredients (\%) & Control & \multicolumn{3}{c}{ Fishmeal : Spirulina meal } \\
\cline { 3 - 5 } & & 28.5 & $50: 50$ & $25: 75$ \\
\hline Fishmeal & 38.0 & 9.5 & 19.0 & 9.5 \\
Spirulina meal & 0.0 & 22.0 & 19.0 & 28.5 \\
Corn flour & 22.0 & 22.0 & 22.0 & 22.0 \\
Soybean meal & 22.0 & 18.0 & 22.0 & 22.0 \\
Tapioca flour & 18.0 & 250 & 250 & 18.0 \\
Add water (ml) & 250 & & 250 \\
\hline
\end{tabular}




\section{Quality Analysis of Floating Fish Feed}

Physical properties analysis of the feed pellets samples from each formulation included the density, floatability, expansion ratio, and hardness. Whilst for the nutritional quality was protein content.

Unit density determined as described by Rosentrater et al. (2009). A random thirty pieces of pellet samples were individually measured in length and diameters with a digital caliper (Mitutoyo Vernier Caliper, Japan) to express volume and weighed using an analytical balance (ViBRA HTR-220E, Japan) to express mass. Average values were then calculated using Eq 1. as unit density number.

Unit density $=\frac{\text { mass of pellet }(\mathrm{mg})}{\text { volume pellet }\left(\mathrm{mm}^{3}\right)}$

Floatability. Thirty pellets samples from each formulation were added into a $1000 \mathrm{ml}$ beaker glass filled with $800 \mathrm{ml}$ distilled water at room temperature. The number of pellets which remained floating in the water after $30 \mathrm{~min}$ was recorded. Floatability was calculated using the following equation (Cruz et al., 2015):

Floatability $(\%)=\frac{\text { number of remained suspended pellet }}{\text { number of total pellet poured }} \times 100$

Expansion ratio. Ratio of the feed diameter against the extruder dies $(3 \mathrm{~mm}$ ) was examined from a total of 30 feed pellets from each formulation, and the expansion ratio was measured using a digital caliper following calculation bellow (Kamaruddin et al., 2018) .

Expansion ratio $=\frac{\text { pellet diameter }(\mathrm{mm})}{\text { dies diameter }(\mathrm{mm})}$

Hardness of the pellets was analyzed using a Texture analyzer (TA-XT2 Stable Micro Systems, England). The value taken was the highest peak before the pellet was broken expressed in Newton (N). Results are based on the average value of 30 samples (Ayadi et al., 2011).

The chemical properties analyzed of raw material were protein, lipid, ash and water content while evaluation for pellets included protein, and water contents. Protein and lipid contents were determined respectively by Kjeldahl and Soxhalet methods, while moisture and ash contents measured by gravimetric method. All the methods performed were in accordance to the Association of Official Analytical Chemist (Association of Official Analytical Chemist, 1990).

\section{Statistical Analysis}

Analysis of each sample formulations were conducted in triplicate. The obtained values were then analyzed by ANOVA (one-way analysis of variance). The means values from different formulations were compared using Tukey's honest significance test set at $P<0.05$. Statistical analysis was conducted using a Minitab version 17 software.

\section{Results and Discussion}

Properties of fish feed pellets included protein and moisture content exhibited at Table 3.

\section{Protein}

Protein content of the floating fish pellets were in range of $35.27-38.89 \%$. The highest protein content $(38.89 \pm 1.26 \%)$ was obtained from the formulation with a 25:75 ratios, while the lowest content $(35.27 \pm 0.18 \%)$ was the control sample (Table 3 ). Inclusion of Spirulina meal into pellets formulation increased the protein content significantly $(P<0.5)$. Amount of protein in fish pellets was in accordance with the level of Spirulina included in formulations since the origin of the protein content of Spirulina used in this research was higher than those of the fishmeal used. It also showed that protein in the Spirulina meal was not noticeably affected by extrusion process in term of its numbers, while other ingredients were constant (Table 1). Protein content in overall pellet formulations showed to meet the minimum amount in accordance to the Indonesian National Standard (SNI) for freshwater fish including Tilapia and Catfish, which is above $28 \%$ of protein content.

This finding is similar to investigation reported by Rosas et al. (2019) and Nainggolan et al. (2015) that find the replacement of fishmeal with Spirulina meal has gradually increased crude protein in the pellets. This suggests that Spirulina meal has potential to substitute fish meal in term of protein content sufficiency in fish feed production.

However, the moisture content of all the pellets showed relatively similar values at around $10 \%$ (wet basis) (see Table 3) with no significant different among the formulations. These amounts have also met the requirement of the $\mathrm{SNI}$ for maximum moisture content in fish feed of a $12 \%$ (wet basis).

\section{Expansion Ratio}

The expansion ratio is an important factor during floating fish feed production since it effects on the unit density, floatability and hardness of the pellets produced. Volume expansion on fish pellet is generated by gelatinization process of the raw material formulation in an extruder. Such case of gelatinization occurs also in pellet formulation containing starch and water (dough) that is received high temperature and high pressure during extrusion. At the end of gelatinization, dough leaves screw-barrel through dies then undergoes puffing phenomenon. This was caused by sudden drop of pressure which causes excessive moisture flash-off and formed pores therein. 
Kamaruddin et al. (2018) observed that during the extrusion process, the water becomes nucleated resulting in formation of bubbles in the extruded materials, and upon exiting the die head the materials are expanded due to sudden moisture evaporation.

The pellets expansion ratio (ER) for the overall formulations were found between $1.57-1.67$ folds. The substitution of fishmeal with 50 and $75 \%$ Spirulina meal in formulations enhanced the ER significantly $(P<0.05)$ (see Table 4). The expansion rate was tending to increase in accordance to Spirulina level in formulations.

According to Rosentrater et al. (2009), increasing fishmeal in aquafeed formulation from 30 to $35 \%$ significantly reduces the expansion ratio for $15.4 \%$, and vice versa. The presence of protein in fishmeal increases mass viscosity thereby restricting expansion ability. Draganovic et al. (2011) also stated, the inclusion of fishmeal was negatively associated with the radial expansion.

However, the use of plant sources of proteins such as Pea protein isolated enhance the expansion properties of rice starch extrudates. In this case, the protein inclusion effects the extrudate expansion through their ability to alter water distribution within the extruded melt (Philipp et al., 2017). Furthermore, Uribe-Wandurraga et al. (2020) found that the sectional expansion index of corn snack is increased when Spirulina platensis biomass is added in formulations.

On the other hand, different result was reported by Martínez-Sanz et al. (2018) that the expansion index is reduced for extruded starch product containing 1-10\% Spirulina. This might be caused by the presence of crystallized fatty acids released from Spirulina intracellular components and promote the formation of V-type complexes with amylose resulting in more densely and well-connected porous structures. Meantime, their research used Spirulina containing a $15.1 \%$ lipid, a $26.7 \%$ protein and a $40.6 \%$ ash. Therefore, lower lipid content of Spirulina used in formulation might result in different outcomes in compared with the present study.

\section{Unit Density}

The unit density of pellets obtained from different formulations were between $0.47-0.63 \mathrm{mg} / \mathrm{mm}^{3}$ (Table 4). Addition of Spirulina meal into formulation tended to reduce the unit density of pellets. Moreover, it also showed that the increment of unit density of the formulated pellets was a contrast to the expansion ratio. In comparison with previous study (Hakim et al., 2019), unit density of the produced pellets in present study were lower than those of pellets containing other protein sources i.e. Hermetia illucens larva meal (0.959 $1.032 \mathrm{mg} / \mathrm{mm}^{3}$ ) and Azolla meal (0.669 - 0.705 $\mathrm{mg} / \mathrm{mm}^{3}$ ).

These results are in agreement with previous works conducted by (Uribe-Wandurraga et al., 2020). When starch flour is combined with Spirulina meal, the diameter of extrudate is increased but those are mixed with Spirulina meal show irregular in diameter. This may be caused by the pore size, which is bigger in pellet with Spirulina meal than the control formula. Kamaruddin et al. (2018) stated that bulk density number of floating fish feed related to porosity forming. More porosity of a pellet resulted in lower in its density number.

\section{Floatability}

Pellets floatability from the overall formulations were in range of $94.28-100 \%$. The highest floatability was obtained at the ratio of 25:75 formulations, which exhibited all floating pellets during 30 minutes. While the lowest floatability was found at the control sample (Table 4). The floatability was significantly different between control and formula incorporated with Spirulina meal $(P<0.05)$ but insignificant among the Spirulina meal contained pellets. An important

Table 3. Nutritional properties of the fish feed pellets

\begin{tabular}{lllc}
\hline Protein sources & Ratio & Protein (\%) & Moisture (\%) \\
\hline Control & & $35.27 \pm 0.18^{\mathrm{a}}$ & $10.29 \pm 1.37^{\mathrm{a}}$ \\
& $75: 25$ & $36.63 \pm 0.53^{\mathrm{b}}$ & $9.68 \pm 1.19^{\mathrm{a}}$ \\
Fish meal : Spirulina meal & $50: 50$ & $38.48 \pm 0.72^{\mathrm{c}}$ & $10.16 \pm 1.52^{\mathrm{a}}$ \\
& $25: 75$ & $38.89 \pm 1.26^{\mathrm{c}}$ & $10.43 \pm 1.39^{\mathrm{a}}$ \\
\hline
\end{tabular}

Values in the same column with different letters indicate significantly different $(P<0.05)$

Table 4. Physical properties of the fish feed pellets

\begin{tabular}{lccccc}
\hline Protein sources & Ratio & $\begin{array}{c}\text { Expansion ratio } \\
(\text { fold })\end{array}$ & $\begin{array}{c}\text { Unit density } \\
\left(\mathrm{mg} / \mathrm{mm}^{3}\right)\end{array}$ & Floatability (\%) & Hardness (N) \\
\hline Control & & $1.57 \pm 0.08^{\mathrm{a}}$ & $0.63 \pm 0.01^{\mathrm{a}}$ & $95.61 \pm 0.79^{\mathrm{a}}$ & $41.17 \pm 1.34^{\mathrm{a}}$ \\
\hline Fish meal : & $75: 25$ & $1.58 \pm 0.13^{\mathrm{ab}}$ & $0.64 \pm 0.07^{\mathrm{ab}}$ & $97.89 \pm 1.89^{\mathrm{ab}}$ & $36.22 \pm 5.15^{\mathrm{ab}}$ \\
Spirulina meal & $50: 50$ & $1.67 \pm 0.12^{\mathrm{b}}$ & $0.52 \pm 0.07^{\mathrm{bc}}$ & $99.44 \pm 0.96^{\mathrm{b}}$ & $34.52 \pm 3.89^{\mathrm{b}}$ \\
& $25: 75$ & $1.65 \pm 0.04^{\mathrm{b}}$ & $0.47 \pm 0.02^{\mathrm{c}}$ & $100.00 \pm 0.00^{\mathrm{b}}$ & $32.53 \pm 1.62^{\mathrm{b}}$ \\
\hline
\end{tabular}

Values in the same column with different letters indicate significantly different $(P<0.05)$ 
parameter that determines the quality of fish feed is its ability to float in water (floatability), whereas fish feed that quickly sinks in water cannot be utilized optimally by fish resulted in in very low efficiency (Mulia et al., 2017).

The floatability of pellets is strongly related to the unit density of the pellets. The smaller unit density the easier fish pellet to float on water due to its lighter structure. Purwasasmita and Roland (2008) mentioned that a pellet will float if the unit density of pellet is lower than density of water i.e. $1 \mathrm{mg} / \mathrm{mm}^{3}$. The experimental result showed all treatments produced pellet with unit density lower than $1 \mathrm{mg} / \mathrm{mm}^{3}$. However, there were found pellets which are not floating. It might be caused by the increased unit density by water intrusion through pellets surface area.

\section{Hardness}

The extrudate hardness essentially refers to physical integrity of the finished product in terms of handling and transport, which relates to the initial rupture of the extrudates. In general, pellet from all formulations had ranging hardness $32.53-41.17 \mathrm{~N}$ (Table 4), with the highest value found at the control sample. Increased level of Spirulina meal in the formulations reduced the hardness which are demonstrated by the pellets with ratio of 50:50 and 25:75 formulations exhibiting significant lower hardness than that of control sample. In contrast, increased level of fishmeal resulted in increased extrudate hardness. Similar result was also reported by (Draganovic et al., 2011) that observed the level of fishmeal and feed moisture were dominant factors influencing the extrudate hardness.

Moreover, the addition of Spirulina for up to $8 \%$ into corn extrudates caused a decrease in hardness (Tańska et al., 2017). Decreasing in hardness by Spirulina inclusion in fish pellet production could be related to the increased expansion and thinner pellet walls (Kraugerud et al., 2011). Fish feed pellets containing larger proportions of plant-derived protein meals showed a lower specific hardness than the reference fish feed, it is likely in regard with the longitudinal expansion which would generate larger lateral surfaces. The texture would thus be more fragile, and less force to break the pellets (Martin et al., 2019).

The hardness of fish feed value is very varied. For instance, Alcaraz et al., (2021) resulted in hardness value of fish feed which added microalgae about 13.63-28.88 N. Further, Kraugerud et al., (2011) stated extruded fish feed have hardness value around 45-107 N while in a commercial extruded fish feed was $46,1 \mathrm{~N}$. A suitable hardness value relied on the user requirement who must consider two factors that were between hardness and floatability. So could be obtained a balance on those physical qualities. Based on result in this study, the reasonable ratio was $25: 75$ in which decreasing hardness value remained within range value but other parameters i.e. expansion ratio, floatability and protein had improved.

\section{Conclusion}

Spirulina meal showed potential for substitution of fishmeal in floating fish feed production. The formulation at ratio of 25:75 (fishmeal: Spirulina meal) resulted the best pellets produced in regards with floatability. The spirulina included formulations produced pellets with higher protein content (38.89\%) and expand ratio (1.65 fold), with the lowest unit density $\left(0.47 \mathrm{mg} / \mathrm{mm}^{3}\right)$ and hardness and the highest floatability (100\%). Therefore, Spirulina meal can be an alternative protein source to improve the protein content and physical quality in floating fish pellet production.

\section{Ethical Statement}

Not applicable

\section{Funding Information}

This research was funded by the Indonesian Research Institute for Fisheries Post-Harvest Mechanization (Ministry of Marine Affairs and Fisheries Republic Indonesia)

\section{Author Contribution}

Arif Rahman Hakim and Putri Wullandari conceptualization and designed the experiment. Tri Nugroho Widiyanto investigation the experiments. Putri Wullandari and Naila Zulfia conducted data analyses. Arif Rahman Hakim, Putri Wullandari and Bakti B Sedayu written and reviewed the manuscript.

\section{Conflict of Interest}

The author(s) declare that they have no known competing financial or non-financial, professional, or personal conflicts that could have appeared to influence the work reported in this paper

\section{Acknowledgements}

The Authors acknowledge Luthfi Assadad, MSc, Head of Research Institute for Fisheries Postharvest Mechanization, who facilitated a Laboratory and equipments to succeed in this research

\section{References}

Alcaraz, R., Hernández-Contreras, A., Iglesias, P., \& Hernández, M.D. (2021). Effect of the inclusion of microalgae on the physical properties of extruded feed for gilthead seabream (Sparus aurata L.). Algal Research, 53(September 2020). https://doi.org/10.1016/j.algal.2020.102167 
Association of Official Analytical Chemist. (1990). Official Methods of Analysis. 15th Edition. Agricultural Chemical; Contaminant; Drugs (K. Helrich (ed.); Vol. 1, Issue Volume 1). Association of Official Analytical Chemist, Inc.

Ayadi, F.Y., Rosentrater, K.A., Muthukumarappan, K., \& Brown, M.L. (2011). Twin-Screw Extrusion Processing of Distillers Dried Grains with Solubles (DDGS)-Based Yellow Perch (Perca flavescens) Feeds. Food and Bioprocess Technology, 5(5), 1963-1978. https://doi.org/10.1007/s11947-011-0535-5

Bambang, N., Utomo, P., Rahmatia, F., \& Setiawati, M. (2012). Penggunaan Spirulina platensis sebagai suplemen bahan baku pakan ikan nila Oreochromis niloticus The use of Spirulina platensis as tilapia Oreochromis niloticus diet supplementation. Jurnal Akuakultur Indonesia, 11(1), 49-53.

Cruz, C.R. De, Kamarudin, M.S., Saad, C.R., \& Ramezani-fard, E. (2015). Effects of extruder die temperature on the physical properties of extruded fish pellets containing taro and broken rice starch. Animal Feed Science and Technology, 236, 137-145. https://doi.org/10.1016/j.anifeedsci.2014.11.010

Draganovic, V., van der Goot, A.J., Boom, R., \& Jonkers, J. (2011). Assessment of the effects of fish meal, wheat gluten, soy protein concentrate and feed moisture on extruder system parameters and the technical quality of fish feed. Animal Feed Science and Technology, 165(34), 238-250. https://doi.org/10.1016/j.anifeedsci.2011.03.004

Hakim, A.R., Handoyo, W.T., Fauzi, A., \& Sarwono, W. (2020). Desain dan Kinerja Mesin Ekstruder Twin Screw untuk Pembuatan Pakan Ikan Terapung. Jurnal Keteknikan Pertanian, 7(2), 129-136. https://doi.org/10.19028/jtep.07.2.129-136

Hakim, A.R., Handoyo, W.T., Novianto, T.D., \& Prasetyo, A.W. (2019). Effects of Twin-Screw Extruders Condition to Physical Properties of Floating Fish Feed. Jurnal Perikanan Universitas Gadjah Mada, 21(2), 79. https://doi.org/10.22146/jfs.44821

Hakim, A.R., Kurniawan, K., \& Siregar, Z.A. (2019). Pengaruh Penggantian Tepung Ikan dengan Tepung Larva Hermetia illucens dan Azolla sp . terhadap Kualitas Pakan Ikan Terapung. Jurnal Riset Akuakultur, 14(2), 77-85. https://doi.org/http://dx.doi.org/10.15578/jra.14.2.201 9.\%25p

Kamaruddin, M.S., de Cruz, C.R., Saad, C.R., Romano, N., \& Ramezani-Fard, N. (2018). Effects of extruder die head temperature and pre-gelatinized taro and broken rice flour level on physical properties of floating fish pellets .pdf. Animal Feed Science and Technology, 236, 122-130. https://doi.org/https://doi.org/10.1016/j.anifeedsci.20 17.12.007

Khanzadeh, M., Esmaeili Fereidouni, A., \& Seifi Berenjestanaki, S. (2016). Effects of partial replacement of fish meal with Spirulina platensis meal in practical diets on growth, survival, body composition, and reproductive performance of three-spot gourami (Trichopodus trichopterus) (Pallas, 1770). Aquaculture International, 24(1), 69-84. https://doi.org/10.1007/s10499-0159909-4

Kraugerud, O.F., Jørgensen, H.Y., \& Svihus, B. (2011). Physical properties of extruded fish feed with inclusion of different plant (legumes, oilseeds, or cereals) meals. Animal Feed Science and Technology, 163(2-4), 244254. https://doi.org/10.1016/j.anifeedsci.2010.11.010
Laining, A., Trismawanti, I., Kamaruddin, K., \& Makmur, M. (2017). Caratenoid-enriched diet for pre-maturation stage of pond-reared tiger shrimp, Penaeus monodon part I. The effects on growth, pigmentation and whole body nutrient content. Indonesian Aquaculture Journal, 12(2), 59-66. https://doi.org/10.15578/iaj.12.2.2017.59-66

Martin, A., Osen, R., Greiling, A., Karbstein, H.P., \& Emin, A. (2019). Effect of rapeseed press cake and peel on the extruder response and physical pellet quality in extruded fish feed. Aquaculture, 512(July), 734316. https://doi.org/10.1016/j.aquaculture.2019.734316

Martínez-Sanz, M., Fabra, M.J., G. Gómez-Mascaraque, L., \& López-Rubio, A. (2018). Structural effects of microalgae additives on the starch gelatinisation process. Food Hydrocolloids, 77, 257-269. https://doi.org/10.1016/j.foodhyd.2017.10.002

Ministry of Marine Affairs and Fisheries. (2017). Indonesia Marine and Fisheries Book. Ministry of Marine and Affairs and Fisheries.

Mulia, D.S., Wulandari, F., \& Maryanto, H. (2017). Uji Fisik Pakan Ikan Yang Menggunakan Binder Tepung Gaplek. Jurnal Riset Sains Dan Teknologi, 1(1), 37-44.

Nainggolan, A., Sudrajat, A.O., Bambang, N., Utomo, P., \& Harris, E. (2015). Peningkatan kinerja reproduksi, kualitas telur, dan larva melalui suplementasi Spirulina dikombinasi dengan injeksi Oocyte dveloper pada induk ikan lele (Clarias sp) betina. Jurnal Riset Akuakultur, 10(2), 199-210.

Philipp, C., Oey, I., Silcock, P., Beck, S.M., \& Buckow, R. (2017). Impact of protein content on physical and microstructural properties of extruded rice starch-pea protein snacks. Journal of Food Engineering, 212, 165173. https://doi.org/10.1016/j.jfoodeng.2017.05.024

Purwasasmita, B.S., \& Roland, P. (2008). Sintesa, karakterisasi dan fabrikasi material berpori untuk aplikasi pelet apung (floating feed). Jurnal Bionatura, 10(1), 13-28.

Raji, A.A., Alaba, P.A., Yusuf, H., Abu Bakar, N.H., Mohd Taufek, N., Muin, H., Alias, Z., Milow, P., \& Abdul Razak, S. (2018). Fishmeal replacement with Spirulina Platensis and Chlorella vulgaris in African catfish (Clarias gariepinus) diet: Effect on antioxidant enzyme activities and haematological parameters. Research in Veterinary Science, 119(April), 67-75. https://doi.org/10.1016/j.rvsc.2018.05.013

Rosas, V.T., Monserrat, J.M., Bessonart, M., Magnone, L., Romano, L.A., \& Tesser, M.B. (2019). Fish oil and meal replacement in mullet (Mugil liza) diet with Spirulina (Arthrospira platensis) and linseed oil. Comparative Biochemistry and Physiology Part - C: Toxicology and Pharmacology, 218(October 2018), 46-54. https://doi.org/10.1016/j.cbpc.2018.12.009

Rosentrater, K.A., Muthukumarappan, K., \& Kannadhason, S. (2009). Effects of ingredients and extrusion parameters on aquafeeds containing DDGS and potato starch. Journal of Aquaculture Feed Science and Nutrition, 1(1), 22-38.

Sheikhzadeh, N., Mousavi, S., Hamidian, G., Firouzamandi, M., Khani Oushani, A., \& Mardani, K. (2019). Role of dietary Spirulina platensis in improving mucosal immune responses and disease resistance of rainbow trout (Oncorhynchus mykiss). Aquaculture, 510(March), 1-8. https://doi.org/10.1016/j.aquaculture.2019.05.009

Tańska, M., Konopka, I., \& Ruszkowska, M. (2017). Sensory, Physico-Chemical and Water Sorption Properties of Corn 
Extrudates Enriched with Spirulina. Plant Foods for Human Nutrition, 72(3), 250-257.

https://doi.org/10.1007/s11130-017-0628-z

Uribe-Wandurraga, Z.N., Igual, M., García-Segovia, P., \& Martínez-Monzó, J. (2020). Influence of microalgae addition in formulation on colour, texture, and extrusion parameters of corn snacks. Food Science and Technology
International.

https://doi.org/10.1177/1082013220924178

Zhang, L., Chen, L., Wang, J., Chen, Y., Gao, X., Zhang, Z., \& Liu, T. (2015). Attached cultivation for improving the biomass productivity of Spirulina platensis. Bioresource Technology, 181, 136-142.

https://doi.org/10.1016/j.biortech.2015.01.025 